\title{
Analisa Kerja Injector Terhadap Perfomance Engine pada Mesin Isuzu Cyz 51
}

\author{
Denur, Syafril \\ Program Studi Mesin Otomotif, Fakultas Teknik \\ Universitas Muhammadiyah Riau \\ Jl. Tuanku Tambusai Ujung, Pekanbaru 28294 \\ E-mail :mridhafauzi@yahoo.co.id
}

\begin{abstract}
The fuel system is classified into the high-pressure system and low pressure system. The high pressure system indicates the parts between supply pump, common rail, injector. The low pressure system indicates the fuel tank, supply pump and fuel leak circuit. There are a number of filters (main, gauze filter etc.) installed in the fuel system Furthermore, in order to prevent fuel leakage and other such problems, a flow damper and pressure limiter are attached to the common rail section, and an overflow valve is attached to the supply pump section. The common rail system using a chamber accumulator type of is so-called functioning rail common for saving of high fuel pressure, and injectors which there are solenoid controlled electronically of valves will spray high fuel pressure into room burn, System Injection ( pressure injection, rate injection, and timing injection) controlled by ECM, and system rail common can control system injection separately, free from influence of speed of machine rotation and machine burden. The Falure of engine will happened degradation of pressure, degradation of hypodermic volume and causing less machine power. Handling of existing damage can be done by treatment intakely data by using special tools and some maintangance procedure.
\end{abstract}

Keywords : Common rail, injector common rail, injection system

\begin{abstract}
Abstrak
System bahan bakar dikelompokan menjadi dua bagian. Bahagian tekanan tinggi dan bahagian tekan rendah. Tekanan tinggi diawali dari komponen supply pump, common rail, injector. Tekanan rendah diawali dari tangki bahan bakar, supply pump dan pipa kelebihan baban bakar. Ada dua buah filter yang digunakan,yaitu filter utama, filter water separator yang difungsikan pada system bahan bakar, untuk mengatasi kebocoran bahan bakar dan berbagai permasalahan yang ada maka sebuah flow damper dan limiter valve di pasang pada bahagian common rail, juga sebuah overflow valve di pasang pada bahagian supply pump. Common rail system yang menggunakan sebuah type accumulator chamber yang disebut common rail yang berfungsi untuk menyimpan tekanan bahan bakar yang tinggi, dan injectors yang terdapat electronically controlled solenoid valves akan menyemprotkan tekanan bahan bakar yang tinggi kedalam ruang bakar, Injection system (injection pressure, injection rate, dan injection timing) dikontrol oleh ECM, dan selanjutnya common rail system dapat mengontrol injection system secara tersendiri, bebas dari pengaruh kecepatan putaran mesin dan beban mesin. Pada kerja mesin yang mengalami kegagalan kerja maka akan terjadi penurunan tekanan, penurunan volume injeksi yang berakibat kurang tenaga mesin. Penanganan dari kerusakan yang ada dapat dilakukan perawatan secara pengambilan data secara menggunakan alat dan percobaan yang dilakukan.
\end{abstract}

Kata kunci: Common rail, injector common rail, injection system

\section{Pendahuluan}

System bahan bakar secara umum berfungsi sebagai jantung dari sebuah mesin, jika mesin tanpa bahan bakar tentunya tidak ada gunanya dan tidak akan ada manfaat dari sebuah mesin. Zaman sekarang mesin diesel dengan perkembangan teknologi common rail menjawab semua keperluan untuk aktifitas. Secara umum teknologi common rail pada berbagai merek mobil prinsip kerja hampir sama hanya ada perbedaan nama dari komponen.

Seiring perkembangan teknologi mesin diesel maka produsen mobil merek isuzu mengeluarkan mesin seri 6WF1TC dengan system bahan bakar dikontrol secara common rail. Mesin dengan system bahan bakar common rail dapat mengabutkan solar dengan tekanan 180 Mpa dan 
dua kali injeksi, injeksi awal atau pilot injeksi, main injeksi atau injeksi normal. Komponen dari common rail yang melaksanakan perintah pengabutan bahan bakar adalah injector yang dikontrol secara elektronik.

Kerja injector akan dipengaruhi oleh kondisi kerja dari kondisi berbagai sensor yang dikontrol dan dikalkulasi data oleh sebuah engine control modul. Baik dan tepat injeksi dari injector juga akan dipengaruhi oleh kualitas bahan bakar, karena dengan bahan bakar yang terlalu banyak karbon atau kadar terkontaminasi oleh air akan mempengaruhi kerja injector. Kendala yang muncul dari kerja injector sudah dapat diatasi oleh produsen pemegang merek mobil dengan perawatan yang dilakukan.

Perawatan untuk sebuah injector bahan bakar dapat dilakukan secara berkala maupun secara reaktif. Secara berkala dilakukan dengan mencampurkan cairan deterjen pembersih injector pada setiap $5000 \mathrm{~km}$ perjalan mobil. Dengan mencapurkan cairan pembersih injector maka kotoran yang ikut masuk dan menumpuk di batang dan ujung jarum injector akan bersih dan ini akan menjadikan kerja injector secara dua tahap, yaitu pase pilot dan pase main injeksi.

Kendaraan dengan system common rail seperti merek isuzu sekarang ini sudah menggunakan system common rail seperti pada mobil isuzu seri CYZ 51 Heavy duty yang banyak digunakan diperusahaan tambang, karena mobil ini menghasilkan tenaga yang besar dengan emisi gas buang yang ramah lingkungan. Namun belakangan ini kerja dari mesin common rail terganggu oleh kadar bahan bakar yang kurang baik seperti bahan bakar yang terkontaminasi air, banyaknya lumpuran kotoran solar di tangki bahan bakar.

Kegagalan kerja mesin seperti kurang tenaga, noise pada putaran idle, rough pada putaran idle, rpm mesin turun naik dan terkontaminasinya solar dengan air terjadi pada sirkulasi bahan bakar. Pada permasalahan yang terjadi pada mobil isuzu seri CYZ51 di perusahaan tambang minyak PT.Chevron keluhan yang terjadi kehilangan tenaga mesin pada suhu kerja 84 derjat celsius.

\subsection{Mesin Common Rail}

Mesin common rail adalah mesin yang bekerja dikontrol secara elektronik dengan tekanan bahan bakar sekitar 30 Mpa sampai 180 Mpa pada supply pump, kemudian tekanan bahan bakar akan dinjeksikan oleh injector yang dikontrol sebuah engine control modul dengan memperhatikan nilai kalkulasi dari berbagai sensor yang ada pada mesin. Manfaat yang besar dengan mesin common rail adalah komsumsi bahan bakar yang irit dan menghasilkan sisa gas buang yang ramah lingkungan.
Perbedaan tekanan, waktu dan volume bahan bakar jika dibandingkan dengan mesin secara konvensional adalah cara memproses bahan bakar yang dimulai dari tangki bahan bakat sampai injector mengabutkan bahan bakar solar.

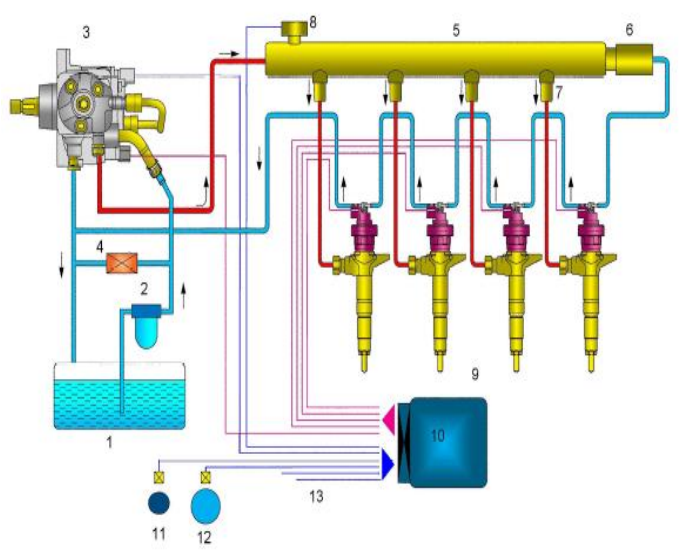

Gambar 1. Common rail system

\section{Keterangan gambar}

1. Tangki bahan bakar

2. Water separator

3. Supply pump

4. One way valve

5. One way valve

6. Common rail tube

7. Limiter valve

8. Dumper valve
9. FRV Sensor

10. Injector

11. Engine

Control

Module

12. CMP

13. CKP

14. Sensor
Cara kerja system common rail adalah bahan bakar dalam tangki dihisap oleh feed pump yang ada di supply pump, melewati water separator untuk memisah kadar air yang ada di kandungan solar. Bahan bakar dinaikan tekananya oleh plunger supply pump terus dikirim ke common rail tube, pipa tekanan tinggi dan injector mengabutkan bahan bakar di dalam silinder mesin. Volume bahan bakar yang dikirim ke common rail tube akan di control oleh kerja dari SCV, FRP sensor dan momen limiter.

Jika SCV mendapat perintah dari ECM untuk penambahan bahan bakar maka arus listrik dari ECM ke SCV akan dihentikan, maka orifice valve akan terbuka penuh akibatnya bahan bakar yang akan dikirim ke plunger, SCV akan off, ini akan menambah volume dan tekanan di common rail tube akan naik hingga batas kerja 220 Mpa. Kerja seperti ini akan terjadi secara constant atau secara terukur yang sesuai dari input data dari berbagai sensor, seperti sensor CMP, CKP, FRP yang dilakukan kalkulasi nilai oleh ECM. Quantitas bahan bakar di injector akan diatur lamamya supply aliran listrik dari ECM ke kumparan injector. 


\subsection{Prinsip Kerja Common Rail}

Bahan bakar yang sudah dihisap oleh pompa minyak dari tangki solar dan melalui saringan akan diteruskan atau dihisap oleh supply pump dan dinaikan tekanan hingga $30 \mathrm{Mpa}$ sampai $180 \mathrm{Mpa}$, bahan bakar akan ditekan ke common rail tube melelui pipa tekanan tinggi, di rail tube bahan bakar akan tertahan atau di simpan hingga tekanan 220 Mpa, bahan bakar yang sudah bertekanan tinggi juga disalurkan ke injector dari rail tube melalui pipa tekan tinggi.

Bahan bakar akan diinjeksikan ke ruang bakar cylinder tergantung lamanya selenoid injector mendapat perintah bekerja dari ECM.

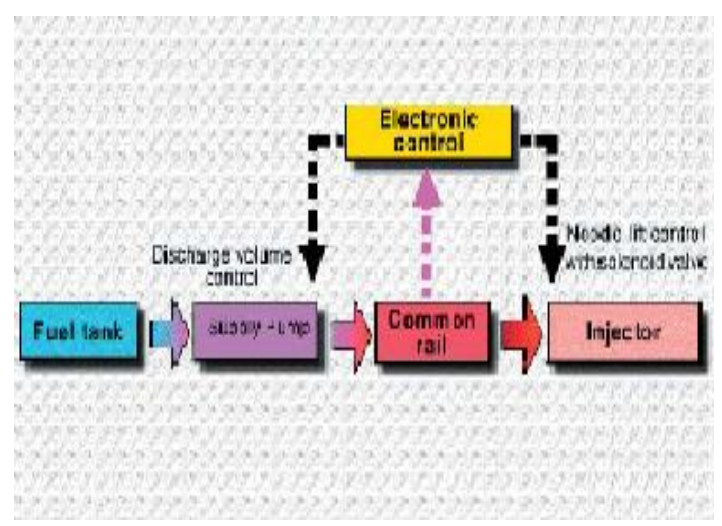

Gambar 2. Kurva karakteristik V - I pada sel surya

\subsection{Perbedaan Conventional dan Common Rail}

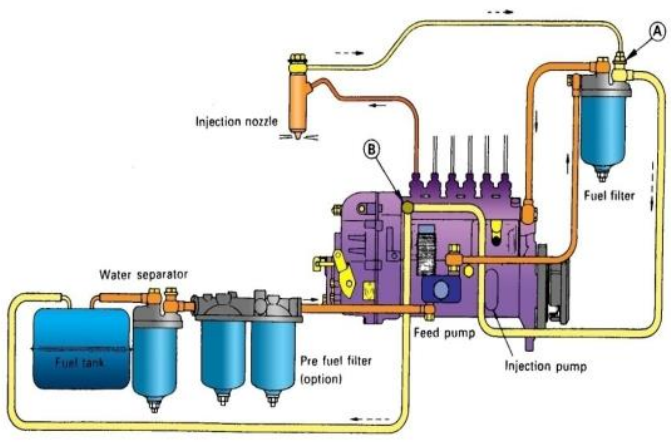

(A). (B); Overfliow Vaive

Gambar 3. Injection pump conventional

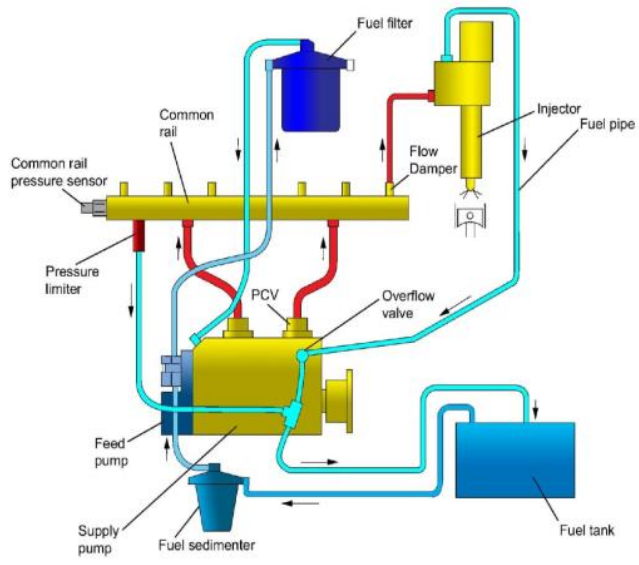

Gambar 4. Injection common rail type

Tabel 1. Perbedaan injection pump conventional dan common rail

\begin{tabular}{lll}
\hline \multicolumn{1}{c}{ System } & \multicolumn{1}{c}{ Inline } & \multicolumn{1}{c}{$\begin{array}{c}\text { Common } \\
\text { Rail }\end{array}$} \\
\hline $\begin{array}{l}\text { Pengaturan } \\
\text { kuantitas injeksi }\end{array}$ & $\begin{array}{l}\text { Governor } \\
\text { type }\end{array}$ & ECM \\
\hline $\begin{array}{l}\text { Pengaturan } \\
\text { timing injeksi }\end{array}$ & $\begin{array}{l}\text { Automatic } \\
\text { timer }\end{array}$ & ECM \\
\hline Peningkatan & Injection & Supply \\
tekanan & pump & pump \\
\hline Distribusi & $\begin{array}{l}\text { Injection } \\
\text { pump }\end{array}$ & $\begin{array}{l}\text { Common } \\
\text { rail }\end{array}$ \\
\hline Pengaturan & $\begin{array}{l}\text { Sesuai } \\
\text { putaran } \\
\text { tekanan injeksi }\end{array}$ & $\begin{array}{l}\text { Supply } \\
\text { pump }\end{array}$ \\
& mesin & \\
\hline
\end{tabular}

Sumber TC IAMI

\subsection{Mekanisme Supply Pump}

Supply pump berfungsi untuk menghisap dan menekan bahan bakar hingga 30 Mpa sampai 180 Mpa dan meneruskan tekanan ke common rail tube melalui pipa tekanan tinggi. Supply pump menggunakan torsi mesin untuk menekan bahan bakar, dan melakukan pengiriman tekanan bahan bakar ke comomon rail tube. Sebagai tambahan supply pump dilengkapi dengan valve tekanan tinggi yang bekerja secara elektronik untuk meningkatkan tekanaan bahan bakar.

Supply pump menggunakan three lobe untuk mengurangi jumlah silinder. Pump supply harus menyediakan sepertiga jumlah silinder mesin. Dengan demikian, kehalusan dan kestabilan tekanan common rail dapat diperoleh, sebab frekwensi bahan bakar yang di pompakan ke common rail adalah sama dengan frekwensi injeksi.

\subsection{PCV ( Pump Control Valve )}

PCV dipasang pada bagian supply pump, dan mengontrol penekanan bahan bakar yang dikirim ( kwantitas pengeluaran bahan bakar ) ke commom 
rail. Engine control module ( ECM ) mengotrol waktu pengiriman listrik ke PCV, sehingga mengontrol jumlah bahan bakar dikeluarkan.

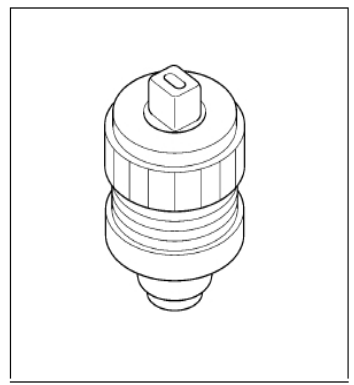

Gambar 5. PCV

Common rail menerima bahan bakar dari supply pump, menjaga tekanan bahan bakar dan mendistribusikan kesetiap silinder. Common rail pressure sensor, flow damper dan limiter dipasang pada common rail.

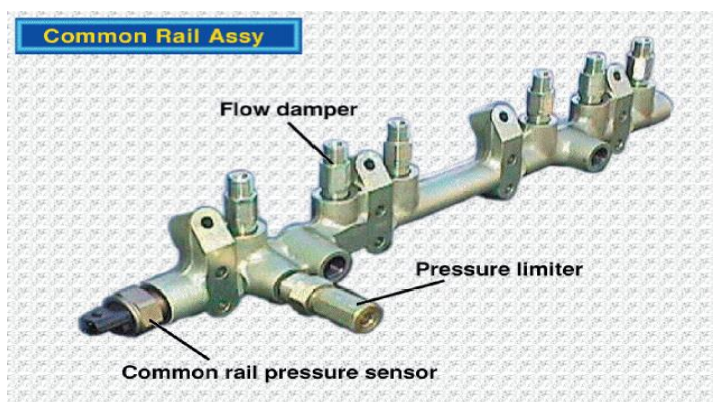

Gambar 6. Common rail tube

\subsection{Fuel Rail Pressure Sensor}

Fuel pressure sensor dipasang pada common rail tube mendeteksi tekanan bahan bakar didalamnaya. Tekanan dikonversikan kedalam tegangan singnal yang dikirimkan ke Engine Control Module (ECM). Tegangan yang lebih tinggi dengan dengan tekanan yang lebih tinggi, dan sebaliknya. ECM menghasilkan tekanan aktual didalam fuel rail dari tegangan signal yang dikirim oleh sensor, yang menggunakanya untuk mengatur penginjeksian bahan bakar.

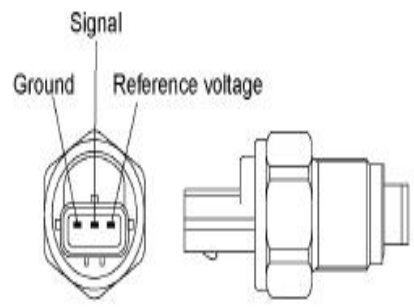

Gambar 7. Pressure sensor

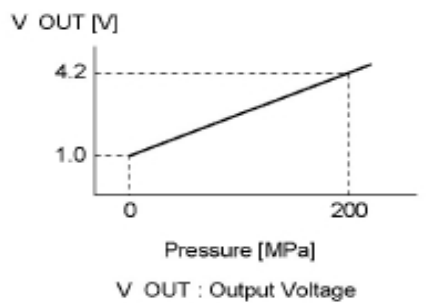

Gambar 8. Diagram kerja sensor

\subsection{Injector}

Injector adalah adalah komponen akhir dari sitem injeksi bahan bakar yang fungsinya untuk mengabutkan bahan bakar dengan tekanan, waktu

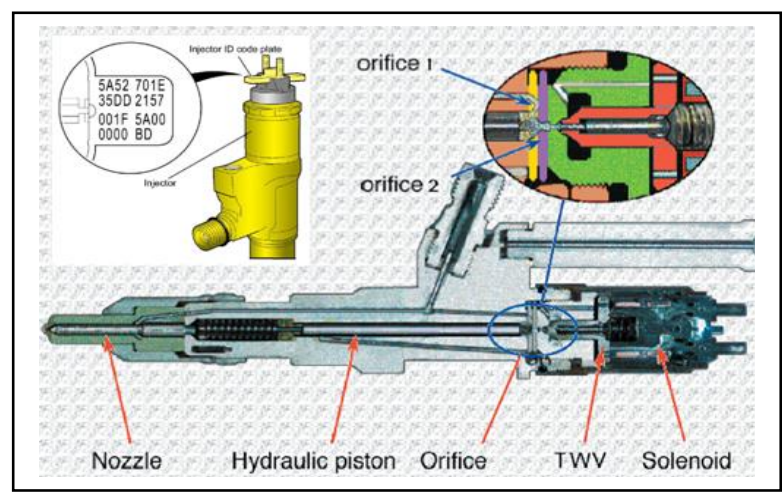

dan volume yang dikontrol oleh ECM.

Gambar 9. Injector Common Rail

Kerja electronic control type injector dikontrol oleh ECM. Dibandingkan dengan conventional injection nozzles, perbedaannya terdapat sebuah common piston, solenoid valve, dan sebagainya. ID code yang tuliskan pada plat atas injector menunjukan variasi karakteristik injector, dan ID code ditunjukan secara numeric, terdapat 30 alphanumeric figure yang ditunjukan dan hanya 24 yang digunakan. System ini digunakan untuk informasi fuel injector flow rate (ID code) yang berguna untuk pengontrolan injection quantity secara optimal.

Saat injector baru dipasang dikendaraan, diperlukan untuk menginput dan memasukkan ID code ke dalam ECM. QR ( Quick Response) code atau ID code fuel injector flow rate dipakai untuk meningkatkan ketepatan jumlah injeksi injector. Penggunaan kode injeksi tersebut memungkinkan jumlah injeksi bahan bakar dikontrol pada semua rentang tekanan injeksi, memberikan kontribusi bagi peningkatan efisiensi pembakaran dan pengurangan emisi gas buang.

\section{Metodologi}

\subsection{Tempat Pelaksanaan}


Labor Mesin Otomotif Fak.Teknik UMRI, Work shop PT. Astra International Isuzu, di Minas dan Duri.

\subsection{Peralatan dan Bahan}

Untuk pelaksanaan pengumpulan data membutuhkan alat-alat sebagai berikut:

Tabel 1. Alat dan Bahan

\begin{tabular}{|c|c|c|}
\hline No & Bahan & Keterangan \\
\hline 1 & $\begin{array}{l}\text { Tech } 2 \text { kit scan } \\
\text { module }\end{array}$ & Digital \\
\hline 2 & Manual book & $\begin{array}{l}\text { Engine } 6 \text { WF1 } \\
\text { common rail }\end{array}$ \\
\hline 3 & Multitester & Digital \\
\hline 4 & Kamera & Digital \\
\hline 5 & Solar & $\begin{array}{l}\text { Bersih dan yang } \\
\text { kotor }\end{array}$ \\
\hline 6 & Injector & $\begin{array}{l}\text { Komponen bagian } \\
\text { dalam }\end{array}$ \\
\hline
\end{tabular}

\subsection{Metode Pelaksanaan}

1. Metode Obsevasi

Melakukan survei langsung kelapangan kerja dan berkomunikasi dengan pengemudi kendaraan tentang hal permasalan terjadi kapan, dimana dan kronologi kejadian.

2. Metode Pengamatan

Melakukan praktek langsung dilapangan untuk mengamati dan menganalisa data data yang didapat langsung dari pengemudi dan dari alat pemeriksaan.

\subsection{Alur Pelaksanaan}

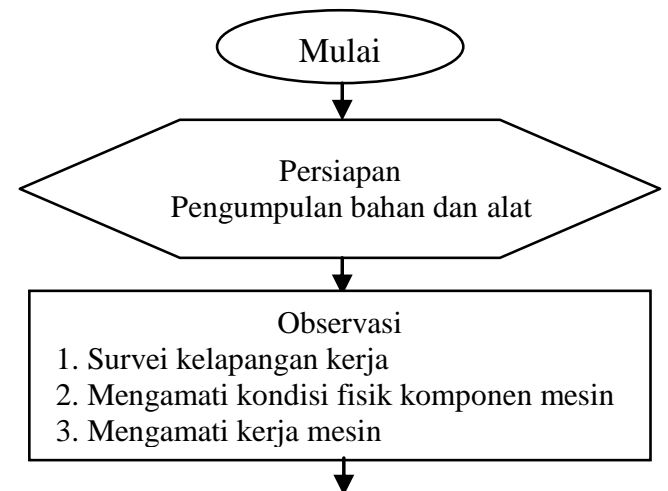

Penelitian

1. Mengambil data aktual kondisi kerja mesin Pada alat tech2

2. Mengamati Analisa data pada parameter tekanan, volume dan timing.

3. Pengujian komponen injector terhadap solar terkontaminasi air.

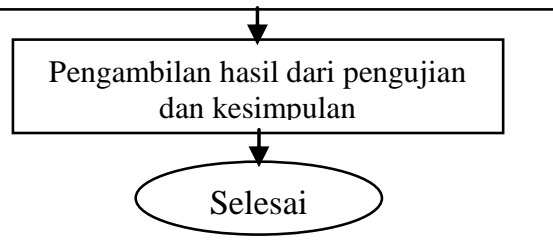

\section{Hasil dan Pembahasan}

\subsection{Spesifikasi CYZ 51.}

Data data tentang kendaraan yang mengalami kegagalan kerja perlu diketahui dan adalah sebagai referensi untuk melakukan analisa pada permasalahan yang terjadi seperti kehilangan daya mesin secara drastis, noise atau suara kasar yang berlebihan pada putarn idle, mesin bergetar atau rough pada rpm rendah, putaran mesin yang tidak stabil dan terkontaminasinya solar dengan air pada system bahan bakar.

Permasalahan yang terjadi pada mesin akan menurunkan performance mesin dan ini diperlukan perawatan yang baik dan terarah dan sesuai dengan nilai yang ada pada spesifikasi kendaraan.

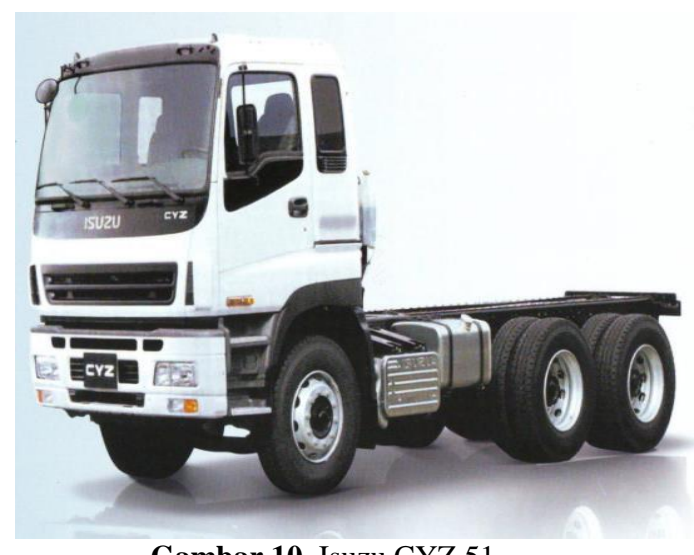

Gambar 10. Isuzu CYZ 51

Rumus performance mesin :

$P S=\frac{T(K g . m) X R P M}{716.2}$

$T(K g \cdot m)=\frac{716.2 X P S}{R P M}$

Tabel 2 Data kendaraan

\begin{tabular}{lcc}
\hline \multicolumn{1}{c}{ Item } & Unit & Specification \\
\hline Mesin & Type & 6WF1 TC \\
\hline No. Cylinder & Pcs & 6 \\
\hline Fuel System & Type & Common rail \\
\hline Cabin tilt & Type & Electric motor \\
\hline \multicolumn{1}{c}{ GVW } & Ton & 26 sampai 32 \\
\hline WB & mm & 4370 \\
\hline Driving & System & $6 \times 4$ \\
\hline $\begin{array}{l}\text { Pinal ratio } \\
\text { gardan }\end{array}$ & & 5,571 \\
\hline Transmisi & Type & MJT7S \\
\hline Brake & Type & ABS \\
\hline Sumber mand
\end{tabular}

Sumber manual book engine 6WF1TC

Dari data speksifikasi bahwa mesin akan bekerja secara electronic dan mengasilkan daya dan torsi yang besar karena kapasitas angkut dari 
kendaraan adalah sangat besar sekitar 26 ton sampai 32 ton.

\subsection{Data Teknik Mesin}

Dengan terjadinya kehilangan daya dan torsi mesin dari nilai ukur yang sandart dan akan mempengaruhi performance mesin, berikut ini data tentang mesin yang mengalami kegagalan kerja sebagai berikut :

\begin{tabular}{|c|c|c|}
\hline ITEM & Unit & Specification \\
\hline Engne model & & 6WF1TC \\
\hline $\begin{array}{l}\text { Applicable } \\
\text { exause emition } \\
\text { Regulation }\end{array}$ & & EURO 2 \\
\hline Engine type & & $\begin{array}{c}\text { Four } \\
\text { circle,over } \\
\text { head cam } \\
\text { shaft, water } \\
\text { cooled }\end{array}$ \\
\hline $\begin{array}{l}\text { Combustion } \\
\text { Chamber } \\
\text { System }\end{array}$ & & $\begin{array}{c}\text { Direct } \\
\text { injection }\end{array}$ \\
\hline $\begin{array}{l}\text { No of cylinder - } \\
\text { bore } \mathrm{x} \text { stroke }\end{array}$ & $\mathrm{M}$ & $\begin{array}{c}6-\emptyset 0.147 \mathrm{x} \\
0.140\end{array}$ \\
\hline Lanjutan & & \\
\hline $\begin{array}{l}\text { Total piston } \\
\text { displacement }\end{array}$ & $\mathrm{Cm}^{3}$ & 14.256 \\
\hline Compresstion & & 17.0 \\
\hline $\begin{array}{l}\text { Maximum } \\
\text { output }\end{array}$ & KW/rpm & $265 / 1800$ \\
\hline & Ps/rpm & $360 / 1800$ \\
\hline $\begin{array}{l}\text { Maximum } \\
\text { torgue }\end{array}$ & N.m/rpm & $1442 / 1100$ \\
\hline & Kgf.m/rpm & $145 / 1100$ \\
\hline $\begin{array}{l}\text { Fuel injection } \\
\text { system }\end{array}$ & & $\begin{array}{c}\text { Common rail } \\
\text { electronic }\end{array}$ \\
\hline $\begin{array}{l}\text { Oil capacity : } \\
\text { Total with oil } \\
\text { filter }\end{array}$ & $\mathrm{L}$ & $22-28.5$ \\
\hline Oil pan & $\mathrm{L}$ & $17-23.5$ \\
\hline $\begin{array}{l}\text { Specified } \\
\text { engine oil ( API } \\
\text { Grade ) }\end{array}$ & & CD CE \\
\hline $\begin{array}{l}\text { Valve clearence } \\
: \text { Intake }\end{array}$ & $\mathrm{mm}$ & 0.40 \\
\hline Exause & $\mathrm{mm}$ & 0.40 \\
\hline Idling speed & RPM & $500 \pm 25$ \\
\hline $\begin{array}{l}\text { Fuel injection } \\
\text { timing }\end{array}$ & ${ }^{\circ} \mathrm{CA}$ & 0 \\
\hline Supply pump & & SP160 - 6HD \\
\hline $\begin{array}{l}\text { Pump } \\
\text { maximum } \\
\text { discharge } \\
\text { amount }\end{array}$ & & $\begin{array}{l}490 \mathrm{~mm} / \\
\text { stroke }\end{array}$ \\
\hline Injector model & & DLL - P \\
\hline $\begin{array}{l}\text { Injection nozzle } \\
\text { number }\end{array}$ & $\mathrm{mm}$ (in) & $\begin{array}{ll}0.19 & (0.0075) \\
-8 & \end{array}$ \\
\hline $\begin{array}{l}\text { Thermostat } \\
\text { open valve }\end{array}$ & ${ }^{\circ} \mathrm{C} /{ }^{\circ} \mathrm{F}$ & $82(180)$ \\
\hline
\end{tabular}

\begin{tabular}{lll}
\hline temperature & & \\
\hline Thermostat & ${ }^{\circ} \mathrm{C} /{ }^{\circ} \mathrm{F}, \mathrm{mm} / \mathrm{in}$ & $95(203) / 11$ \\
totally open & & $(0.433)$ \\
temperatur & & \\
\hline
\end{tabular}

Sumber Manual Book Isuzu 6WF1

Dengan melihat data teknik mesin diatas sebagai berikut

1. Daya maximum mesin $265 / 1800 \mathrm{kw} /$ rpm atau 360 / 1800 ps / rpm

2. Tourque maximum 1442 / $1100 \mathrm{Nm} / \mathrm{rpm}$ atau 145 / $1100 \mathrm{Kgf.m} / \mathrm{rpm}$

3. Fuel injection timing $0^{\circ} \mathrm{CA}$ atau TDC

4. Fuel system common rail electronic

\subsection{Data aktual kerja mesin pada alat tech2}

Untuk mendapatkan hasil analisa maka parameter kerja system common rail seperti pengaturan tekanan, pengaturan volume injeksi dan pengaturan waktu injeksi dibutuhkan sebagai nilai satandart.

\subsubsection{Parameter tekanan bahan bakar}

Mesin 6WF1TC dengan pengaturan system common rail dengan tekanan $30 \mathrm{Mpa}$ sampai 180 Mpa diberikan oleh supply pump. Tekanan akan diteruskan ke common rail tube dengan maximum tekanan normal hingga $220 \mathrm{Mpa}$. Limiter valve akan membebaskan tekanan di common rail tube jika melebihi 220 Mpa. Pengaturan tekanan dikontrol secara electronic dengan kerja FRP, input data dari common rail tube ke ECM dan akhirnya memerintahkan PCV bekerja sebagai actuator. Tekanan pembukaan injector akan terkontrol di 180 Mpa yang bekerja secara electronic dengan solenoid sebagai actuator.

\subsubsection{Parameter volume bahan bakar}

Jumlah bahan bakar yang ditekan oleh supply pump ke common rail tube sekitar $490 \mathrm{~mm}^{3}$ / stroke. Bahan bakar akan dikirim secara normal yang diatur oleh sensor rail tube dan pump control valve. Rata rata jumlah bahan bakar yang di injeksikan oleh injector adalah sekitar 28.9 $\mathrm{mm}^{3} /$ stroke dengan nilai koreksi lebih kurang 5 $\mathrm{mm}^{3} /$ stroke ( sumber manual book, data tech2 6WF1 ).

\subsubsection{Parameter injection timing}

Waktu injeksi bahan bakar oleh injector pada suhu kerja mesin sebelum normal akan berubah rubah tergantung pada suhu pendingin dan tempratur bahan bakar. Pada suhu kerja normal mesin waktu injeksi adalah 0 crank angle ( sumber data teknik mesin 6WF1). 
Tabel 3. Nilai standart parameter kerja mesin dan injector

\begin{tabular}{|l|c|c|}
\hline \multicolumn{1}{|c|}{ Item } & Unit & Nilai \\
\hline $\begin{array}{l}\text { Common rail } \\
\text { pressure }\end{array}$ & Mpa & $-0,6$ \\
\hline Injection fuel rate & $\mathrm{mm}^{3} /$ stroke & 28,9 \\
\hline $\begin{array}{l}\text { Balancing rate } \\
\text { cylinder No 1 }\end{array}$ & $\mathrm{mm}^{3} /$ stroke & \pm 5 \\
\hline $\begin{array}{l}\text { Balancing rate } \\
\text { cylinder No 2 }\end{array}$ & $\mathrm{mm}^{3} /$ stroke & \pm 5 \\
\hline $\begin{array}{l}\text { Balancing rate } \\
\text { cylinder No 3 }\end{array}$ & $\mathrm{mm}^{3} /$ stroke & \pm 5 \\
\hline $\begin{array}{l}\text { Balancing rate } \\
\text { cylinder No 4 }\end{array}$ & $\mathrm{mm}^{3} /$ stroke & \pm 5 \\
\hline $\begin{array}{l}\text { Balancing rate } \\
\text { cylinder No 5 }\end{array}$ & $\mathrm{mm}^{3} / \mathrm{stroke}$ & \pm 5 \\
\hline $\begin{array}{l}\text { Balancing rate } \\
\text { cylinder No 6 }\end{array}$ & $\mathrm{mm}^{3} / \mathrm{stroke}$ & \pm 5 \\
\hline $\begin{array}{l}\text { Injector balancing } \\
\text { test no 1 on }\end{array}$ & $\mathrm{RPM}$ & 521 \\
\hline $\begin{array}{l}\text { Injector balancing } \\
\text { test no.2 on }\end{array}$ & $\mathrm{RPM}$ & 525 \\
\hline $\begin{array}{l}\text { Injector balancing } \\
\text { test no.3 on }\end{array}$ & $\mathrm{RPM}$ & 510 \\
\hline $\begin{array}{l}\text { Injector balancing } \\
\text { test no.4 on }\end{array}$ & $\mathrm{RPM}$ & 515 \\
\hline $\begin{array}{l}\text { Injector balancing } \\
\text { test no.5 on }\end{array}$ & $\mathrm{RPM}$ & 510 \\
\hline $\begin{array}{l}\text { Injector balancing } \\
\text { test no.6 on }\end{array}$ & $\mathrm{RPM}$ & 515 \\
\hline $\begin{array}{l}\text { Injection timing } \\
\text { pada }\end{array}$ & $\mathrm{CA}$ & 0 \\
\hline Sum mant & \\
\hline
\end{tabular}

Sumber manual book, data aktual tech2 6WF1

Dengan melihat data diatas yaitu:

1. Nilai koreksi tekanan common rail - $6 \mathrm{Mpa}$

2. Injection fuel rate injector $28.9 \mathrm{~mm}^{3} / \mathrm{stroke}$ dengan nilai koreksi untuk setiap injector $\pm 5 \mathrm{~mm}^{3} / \mathrm{stroke}$

3. Injector balancing test actuator rpm $500 \pm 25$

\subsection{Hasil Data pada Tech2}

Parameter aktual kerja mesin dapat dibaca oleh alat dan merupakan referensi analisa hilangnya perfompance mesin.

Hasil data pada tech2:

1. Tekanan bahan bakar dalam batas nilai, 30 Mpa sampai 180 Mpa dengan nilai actual pada data disply tech2 minus 0,6 Mpa

2. Volume injeksi berfariasi pada batas nilai kelebihan injeksi $5 \mathrm{~mm}^{3} /$ stroke dan kekurangan injeksi $5,0 \mathrm{~mm}^{3} /$ stroke

3. RPM mesin saat dilakukan test balancing actuator test, suara dan rpm mesin tidak turun secara drastis.

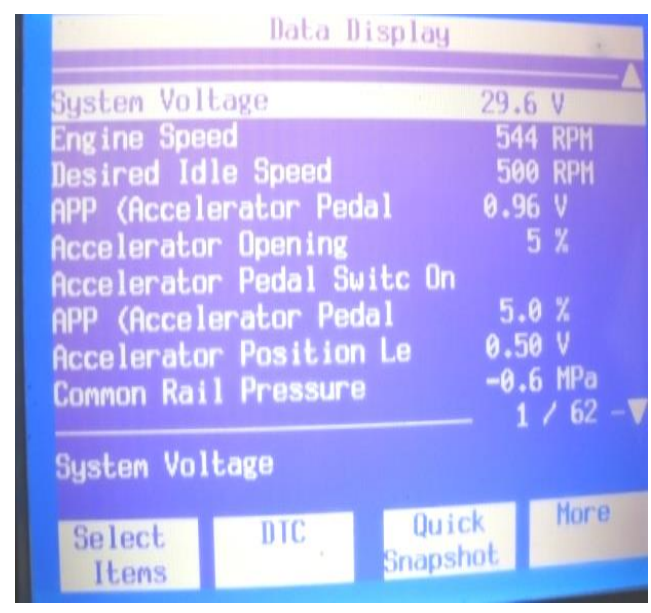

Gambar 11. Pressure fuel rail

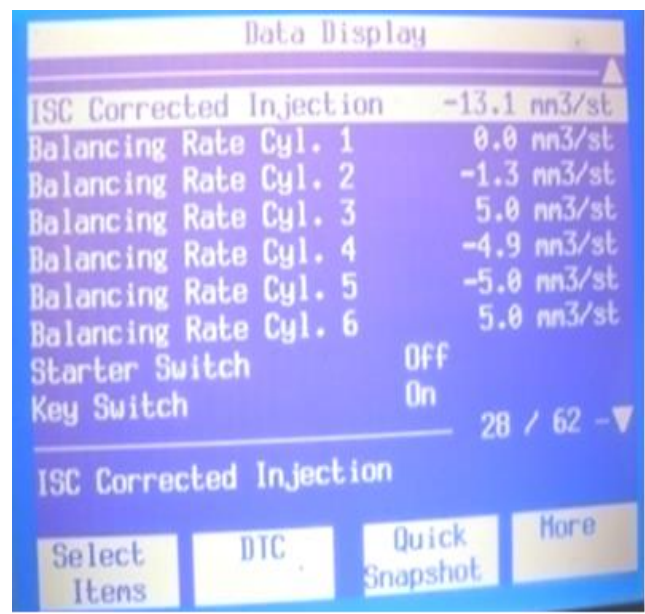

Gambar 12. Fuel rate injectors

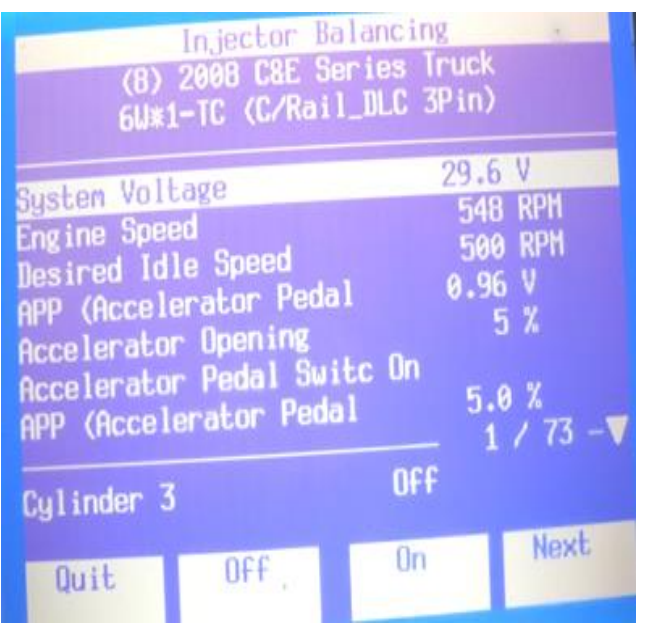

Gambar 13. Injector balancing saat on 


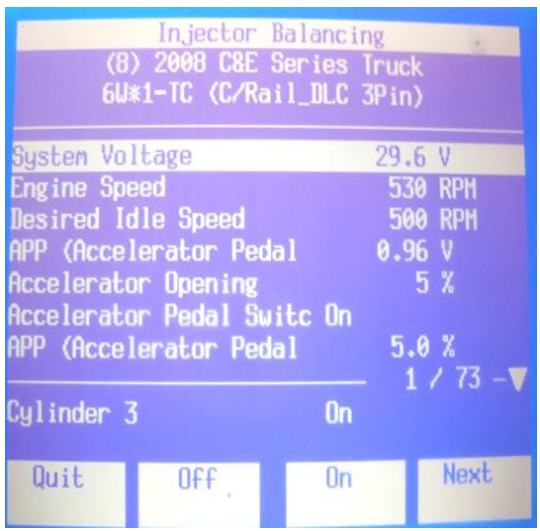

Gambar 14. Injector balancing saat off

Tabel 4. Hasil data pada tech2

\begin{tabular}{|c|l|c|c|c|}
\hline NO & \multicolumn{1}{|c|}{ ITEM } & KONDISI & $\begin{array}{c}\text { NILAI UKUR } \\
\text { STANDAR }\end{array}$ & HASIL UKUR \\
\hline 1 & Putaran idle ( rpm $)$ & Rough & $500 \pm 25$ & 548 \\
\hline 2 & Suara mesin & Knocking & Not noise & Noise \\
\hline 3 & DTC & Not present & NO DTC & NO DTC \\
\hline 4 & Fuel pressure regulation & Normal & Max $60 \mathrm{Mpa}$ & $32 \mathrm{Mpa}$ \\
\hline 5 & Common rail pressure & Normal & $-6 \mathrm{Mpa}$ & $-6 \mathrm{Mpa}$ \\
\hline 6 & Injector balancing & Upnormal & $\begin{array}{c}\text { RPM } \\
\mathrm{ke} \pm 25\end{array}$ & $\begin{array}{c}\text { RPM } \\
\text { Turun ke } 530\end{array}$ \\
\hline 7 & Injector fuel rate & Upnormal & $\pm 5 \mathrm{~mm} 3 / \mathrm{st}$ & $\pm 5 \mathrm{~mm} 3 / \mathrm{st}$ \\
\hline 8 & Solar & Upnormal & Berwarna putih \\
\hline 9 & Water separator & Upnormal & Gelas bening & Gelas kabur \\
\hline 10 & Sensor FRP & Normal & $10 \mathrm{M} \Omega$ or more & $10.25 \mathrm{M} \Omega$ \\
\hline 11 & Injector nozzle & Upnormal & Abu abu & Hitam berarang \\
\hline 12 & Fuel lamp indicator & ON & Off when idling & ON \\
\hline 13 & ECT & Normal & $84^{\circ} \mathrm{c}$ & $84^{\circ} \mathrm{C}$ \\
\hline
\end{tabular}

Sumber manual book, data tech

\subsection{Pengujian yang dilakukan}

Pada pengujian yang dilakukan adalah dengan cara merendam komponen injector dengan solar yang bercampur dengan air selama satu minggu untuk mendapatkan data perubahan material pada komponen injector. Percobaan kedua, komponen injector direndam dengan solar bersih dari SPBU selama satu minggu.

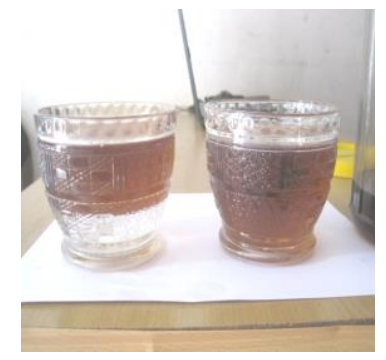

Gambar 15. Solar bersih dan bercampur air

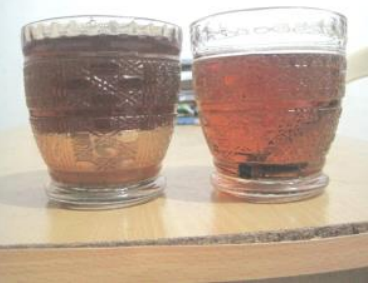

Gambar 16. Solar bersih dan bercampur air

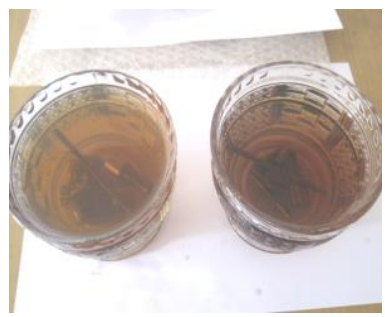

Gambar 17. Uji rendam komponen injector 


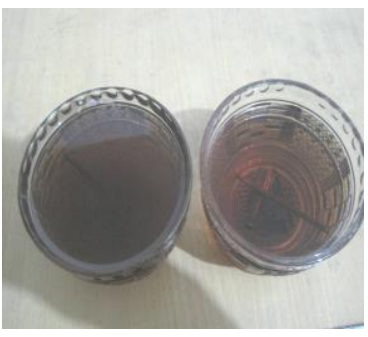

Gambar 18. Uji rendam komponen injector

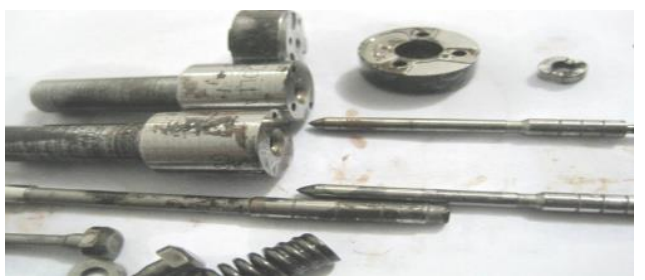

Gambar 19. Komponen injector pada solar yang bercampur air

Dari hasil pengujian solar yang dilakukan didapat sebagai berikut

1. Bahan bakar yang bersih dan bebas dari kotoran dan air akan memberikan efek yang baik terhadap material injector

2. Bahan bakar yang kotor dan terkontaminasi oleh air akan mebuat komponen injector berkarat

3. Karat pada bagian jarum injector akan mengikis material lapisan diamond ligh carbon yang mempunyai fungsi ketahanan terjadinya karat dan membantu proses pemuaian yang baik pada jarum injector

4. Bahan bakar yang terkontaminasi air akan mengendapkan lumpur, kotoran pada dasar wadah bahan bakar

\subsection{Hasil Analisa}

Setelah melakukan tahapan pengamatan dilapangan dengan mengambil data yang menggunakan peralatan tech2 dan juga melakukan pengujian komponen injector yang direndam dengan solar yang bersih dan solar yang terkontaminasi air selama enam hari, maka didapat hasil analisa dari kegagalan performance mesin sebagai berkut

1. Tekanan fuel rail dalam batas kerja dengan nilai 31.9 Mpa dan nilai koreksi minus 6 Mpa pada rpm idling yang ditandai dengan tidak adanya DTC, MIL pada meter cluster adalah off

2. Volume injeksi bahan bakar pada suhu normal kerja mesin adalah dibatas akhir nilai yang ditentukan yaitu lebih kurang 5 $\mathrm{mm}^{3} /$ stroke, maka potensi kekurangan volume injeksi oleh injector bisa terjadi.

3. Pada saat melakukan balancing test actuator atau uji kerja injector, rpm mesin tidak berubah ketika di common off dan common on, ini menandakan kerusakan pada injector, akibatnya injector fuel rate yang diinjeksikan oleh injector adalah kurang banyak atau low consumtion fuel.

4. Akibat terkontaminasinya solar dan air maka komponen injector berkarat yang berakibat kerusakan pada jarum injector, tersumbatnya orifice inlet dan outlet pada common chamber injector.

5. Karat pada jarum injector akan membuat gesekan ke nozzle holder maka lapisan diamond ligh carbon pada jarum injector akan hilang, ini akan membuat proses pemuaian jarum injector dan gerakan jarum tersendat sendat pada holdernya

6. Solar yang terkontaminasi air akan mengakibatkan kerusakan fatal pada komponen injector dengan terjadinya pengkaratan

7. Kotoran yang terbentuk dari hasil pencampuran solar dan air akan menumpuk didasar tangki bahan bakar dan feed pump akan menghisap kotoran dan masuk ke fuel filter, supply pump, fuel rail dan injector.

\subsection{Tindakan yang dilakukan pada permasalahan yang terjadi}

1. Bersihkan bahagian dalam tangki solar

2. Bersihkan atau ganti saringan solar pada water separator

3. Ukur tahanan internal pada switch water separator

4. Nilai tahanan water separator switch $220 \mathrm{k} \Omega$ indicator lamp off

5. Nilai tahanan water separator switch 47 sampai $100 \mathrm{k} \Omega$ indicator lamp on

6. Ganti switch water separator jika nilai tahanan melebihi

7. Bersihkan atau ganti saringan solara utama

8. Bersihkan atau ganti strainer solar pada supply pump

9. Ukur tahanan internal pada solenoid pump control valve

10. Nilai tahan pump control valve $3.2 \Omega$

11. Ganti pump control valve jika tahanan melebihi

12. Bersihkan fuel rail tube

13. Bersihkan fuel rail pressure valve

14. Bersihkan atau ganti folw damper valve

15. Bersihkan atau ganti pipa tekanan tinggi injector 
16. Ganti injector yang diketahui rusak dari uji balancing test

17. Untuk kesempurnaan volume injeksi ganti semua injector

18. Ganti injector ID code dengan nomor yang baru dan program ke ECM

19. Running mesin sampai suhu kerja normal sekitar $84^{\circ} \mathrm{C}$

20. Gunakan tech 2 untuk melihat parameter kerja mesin

21. Periksa parameter fuel rail pressure

22. Periksa parameter balancing Injector fuel rate
23. Periksa parameter injector balancing test actuator saat common off dan on

24. Lakukan test drive dan rekam data dengan snapshot menu

25. Periksa nilai balncing injector fuel rate saat test drive

26. Nilai standar $0.0 \mathrm{~mm}^{3} /$ stroke dengan koreksi nilai lebih kurang $5 \mathrm{~mm}^{3} /$ stroke pada masing masing injector

27. Periksa parameter tempratur kerja mesin

28. Jika nilai masih dalam batas pemakaian maka performance mesin sudah dapat teratasi dengan baik

Tabel 5. Hasil pengujian injector

\begin{tabular}{|c|c|c|c|c|}
\hline \multirow{2}{*}{ Hari } & \multicolumn{2}{|c|}{ Kondisi Solar } & \multicolumn{2}{c|}{ Kondisi Nozzle pada } \\
\cline { 2 - 5 } & Solar bersih & Solar bercampur air & $\begin{array}{c}\text { Solar } \\
\text { bersih }\end{array}$ & Solar bercampur air \\
\hline Pertama & Bersih & Warna putih & Tetap & Tetap \\
\hline Ke dua & Bersih & Mulai menghitam & Tetap & Mulai kotor \\
\hline Ke tiga & Bersih & Putih saat diaduk & Tetap & Menghitam \\
\hline Ke empat & Bersih & Puth berkarat & Tetap & Berkarat sebagian \\
\hline Ke lima & Bersih & Putih kotor & Tetap & Berkarat \\
\hline Ke enam & Bersih & Putih kotor & Tetap & Berkarat \\
\hline
\end{tabular}

Sumber aktual uji solar

Tabel 6. Hasil analisa

\begin{tabular}{|c|c|c|c|}
\hline Item & Nilai standart & Before repair & After repair \\
\hline Fuel rail pressure & $60 \mathrm{Mpa}$ & $32 \mathrm{Mpa}$ & $31.9 \mathrm{Mpa}$ \\
\hline Injector fuel rate cyl no 1 & $\pm 5 \mathrm{~mm}^{3} / \mathrm{st}$ & $0,0 \mathrm{~mm}^{3} / \mathrm{st}$ & $0,0 \mathrm{~mm}^{3} / \mathrm{st}$ \\
\hline Injector fuel rate cyl no 1 & $\pm 5 \mathrm{~mm}^{3} / \mathrm{st}$ & $-1,3 \mathrm{~mm}^{3} / \mathrm{st}$ & $0,0 \mathrm{~mm}^{3} / \mathrm{st}$ \\
\hline Injector fuel rate cyl no 1 & $\pm 5 \mathrm{~mm}^{3} / \mathrm{st}$ & $5,0 \mathrm{~mm}^{3} / \mathrm{st}$ & $0,0 \mathrm{~mm}^{3} / \mathrm{st}$ \\
\hline Injector fuel rate cyl no 1 & $\pm 5 \mathrm{~mm}^{3} / \mathrm{st}$ & $-4,9 \mathrm{~mm}^{3} / \mathrm{st}$ & $0,0 \mathrm{~mm}^{3} / \mathrm{st}$ \\
\hline Injector fuel rate cyl no 1 & $\pm 5 \mathrm{~mm}^{3} / \mathrm{st}$ & $-5,0 \mathrm{~mm}^{3} / \mathrm{st}$ & $0,0 \mathrm{~mm}^{3} / \mathrm{st}$ \\
\hline Injector fuel rate cyl no 1 & $\pm 5 \mathrm{~mm}^{3} / \mathrm{st}$ & $5,0 \mathrm{~mm}^{3} / \mathrm{st}$ & $0,0 \mathrm{~mm}^{3} / \mathrm{st}$ \\
\hline Injector balancing cyl no 1 & $500 \pm 25$ & $\begin{array}{c}548 \\
\text { ( RPM tetap ) }\end{array}$ & $\begin{array}{c}526 \\
\text { ( RPM turun ) }\end{array}$ \\
\hline Injector balancing cyl no 1 & $500 \pm 25$ & $\begin{array}{c}548 \\
\text { ( RPM tetap ) } \\
\end{array}$ & $\begin{array}{c}526 \\
\text { ( RPM turun ) } \\
\end{array}$ \\
\hline Injector balancing cyl no 1 & $500 \pm 25$ & $\begin{array}{c}548 \\
\text { ( RPM tetap ) }\end{array}$ & $\begin{array}{c}526 \\
\text { ( RPM turun ) }\end{array}$ \\
\hline Injector balancing cyl no 1 & $500 \pm 25$ & $\begin{array}{c}548 \\
\text { ( RPM tetap ) }\end{array}$ & $\begin{array}{c}526 \\
\text { ( RPM turun ) }\end{array}$ \\
\hline Injector balancing cyl no 1 & $500 \pm 25$ & $\begin{array}{c}548 \\
\text { ( RPM tetap ) }\end{array}$ & $\begin{array}{c}526 \\
\text { ( RPM turun ) }\end{array}$ \\
\hline Injector balancing cyl no 1 & $500 \pm 25$ & $\begin{array}{c}548 \\
\text { ( RPM tetap ) } \\
\end{array}$ & $\begin{array}{c}526 \\
\text { ( RPM turun ) } \\
\end{array}$ \\
\hline DTC & NOT present & $\begin{array}{c}\text { NOT } \\
\text { present }\end{array}$ & $\begin{array}{l}\text { NOT } \\
\text { present }\end{array}$ \\
\hline Suhu kerja mesin & $84^{\circ} \mathrm{c}$ & $84^{\circ} \mathrm{c}$ & $84^{\circ} \mathrm{c}$ \\
\hline Torsi mesin ( Kg.m ) & 145 & 71.62 & 136 \\
\hline
\end{tabular}

Sumber manual book, data actual tech2

\section{Kesimpulan}

Dari hasil data pada alat tech2 dan dari hasil pengujian komponen injector yang direndam dengan solar yang terkontaminasi air selama enam hari dapat disimpulkan sebagai berikut: 
1. Terkontaminasinya solar dan air mengakibatkan kerusakan fatal pada injector

2. Volume injeksi injector kurang banyak pada saat tempratur kerja mesin

3. Karat yang terjadi pada jarum nozzle akan menghilangkan diamond ligh carbon

4. Proses pemuain jarum injector tidak baik dan gerakan jarum tesendat sendat pada holdernya, akibatnya fuel rate low consunsumtion

5. Pada test balancing injector atau uji kerja injector, rpm mesin tidak berubah saat common on dan common off

\section{Daftar Pustaka}

PT. Pantja Motor, Service Department, Isuzu Training Center, Advance, pub ISZTM/ADV-2.

PT. IAMI, Manual Book CYZ.

PT. IAMI, Training manual advance Engine 4jj1, Engine Mechanical feature, Engine Control System dan diagnose.

PT. Pantja Motor, Product Knowledge C dan E Series.

Wiranto Arismunandar, Koichi Tsuda, Motor Diesl Putaran Tinggi.

Rabiman, Zainal Arifin, Sistem Bahan Bakar Motor Diesel.

Isusu tech2 scan tool kit, data disply engine $6 \mathrm{wf1}$ TC

www.akautomotivetraining.co.uk/AK Training/Tony Kichen.

www.Diagram Alur Untuk Program Komputer .com.

PT. Pantja Motor, Isuzu Training Center,Training Manual Basic.

Ir.Patar TP. Hutauruk, Gunawan, Dasar Dasar Kendaraan Isusu, Service Isuzu Training Center, Edisi ke- 1.

Ir.Patar TP. Hutauruk, Gunawan, Dasar Dasar Kendaraan Isusu, Service

Isuzu Training Center, Edisi ke- 1. 